\title{
Effect of a plant histaminase on asthmalike reaction induced by inhaled antigen in sensitized guinea pig
}

\author{
Emanuela Masini ${ }^{\mathrm{a}, *}$, Alfredo Vannacci ${ }^{\mathrm{a}}$, Lucia Giannini ${ }^{\mathrm{a}}$, Olivia Befani ${ }^{\mathrm{b}}$, Silvia Nistri ${ }^{\mathrm{c}}$, \\ Mircea Alexandru Mateescu ${ }^{\mathrm{d}}$, Pier Francesco Mannaioni ${ }^{\mathrm{a}}$, Bruno Mondovi $^{\mathrm{c}}$, Rodolfo Federico ${ }^{\mathrm{e}}$ \\ ${ }^{a}$ Department of Preclinical and Clinical Pharmacology, University of Florence, Viale G. Pieraccini, 6, 50139 Florence, Italy \\ ${ }^{\mathrm{b}}$ Department of Biochemical Sciences, “A. Rossi Fanelli" and CNR Center of Molecular Biology, University "La Sapienza", Rome, Italy \\ ${ }^{\mathrm{c}}$ Department of Anatomy, Histology and Forensic Medicine, Section of Histology, University of Florence, Florence, Italy \\ ${ }^{\mathrm{d}}$ Department of Chemistry and Biochemistry, Université du Quebec, Montréal, Canada \\ ${ }^{\mathrm{e}}$ Department of Biology, University of Rome 3, Rome, Italy
}

Received 12 July 2004; received in revised form 20 August 2004; accepted 1 September 2004

Available online 23 September 2004

\begin{abstract}
This study evaluates the effects of a copper amine oxidase (histaminase) purified from the pea seedling as a free or immobilized enzyme on asthmalike reactions to inhaled antigen in actively sensitized guinea pig in vivo. Male albino guinea pigs, sensitized with ovalbumin, were challenged with the antigen given by aerosol; free histaminase or CNBr-Sepharose immobilized histaminase was given intraperitoneally (20 $\mu \mathrm{g}, 3$ or $24 \mathrm{~h}$ before antigen challenge) or by aerosol (4 $\mu \mathrm{g}, 30 \mathrm{~min}$ before or during ovalbumin aerosol). The following parameters were examined: latency time for the onset of respiratory abnormalities, cough severity score, and occurrence and duration of dyspnea. We also evaluated lung histopathology, mast cell degranulation, and lung myeloperoxidase and malonydialdehyde levels.

Histaminase significantly reduced the severity of cough and the occurrence of dyspnea and delayed the onset of respiratory abnormalities. Both enzymes prevented bronchial constriction, pulmonary air space inflation, leukocyte infiltration (evaluated as myeloperoxidase activity), and lipoperoxidation of cell membranes (evaluated as malonyldialdehyde production). No relevant differences in pharmacological potency were noted between free or immobilized enzyme.

This study provides evidence that histaminase counteracts acute allergic asthmalike reaction in actively sensitized guinea pigs, raising the possibility of new therapeutic strategies for allergic asthma in humans.
\end{abstract}

(C) 2004 Elsevier B.V. All rights reserved.

Keywords: Pea seedling histaminase; Amine oxidase; Asthmalike reaction; Histamine; Mast cell; Leukocyte; Free radical

\section{Introduction}

Asthma is a major medical problem but despite decades of research the therapy of this pathological condition has remained essentially unchanged for the past 30 years. In recent years, only few new drugs were proposed for the treatment of asthma, among them leukotriene receptor antagonists (Drazen, 1999), antiimmunoglobulin E anti-

\footnotetext{
* Corresponding author. Tel.: +39 55 4271233; fax: +39 554271280

E-mail address: emanuela.masini@unifi.it (E. Masini).
}

bodies, and phosphodiesterase inhibitors (Spina and Page, 2002a; Sullivan and Meltzer, 2003). Asthma morbidity has increased worldwide especially among children (Myers, 2000; Hartert and Peebles, 2000). At the moment, there is a continuous interest in novel therapeutic molecules, showing powerful antioxidant properties for the treatment of asthma.

Direct evidence for the role of free radicals in asthma comes from human studies showing higher antioxidants levels in the respiratory tract of asthmatics than in normal subjects (Comhair et al., 1999), and that the level of bronchial obstruction in asthma is associated with an 
increased production of oxygen free radicals from inflammatory cells in airway lumen (Calhoun et al., 1992). Mast cells have long been considered to be of paramount importance in the pathophysiology of asthma (Rossi and Olivieri, 1997). In fact, the release of immunoglobulin E (IgE)-dependent mediators, such as histamine from mast cells, plays a central role in the pathogenesis of diseases such as allergic asthma (Galli, 1993; Bradding and Holgate, 1996; Page et al., 2001). In fact, it has been shown that the number of mast cells in the smooth muscle of patients with asthma is inversely correlated with the degree of airway hyperresponsiveness (Brightling et al., 2002).

Amine oxidases are ubiquitous enzymes widely distributed among living organisms (Mondovì, 1985), which catalyze the oxidation of monoamines and polyamines. Histamine and other primary amines released during anaphylactic reaction undergo oxidative deamination by amine oxidase with release of corresponding aldehyde, ammonia, and hydrogen peroxide (Mondovi et al., 1988). Amine oxidases can be divided into two classes, depending on whether the prosthetic group is flavin adenine dinucleotide or 2,4,5 trihydroxyphenylalanine quinone (TPQ), a cofactor derived from the posttranslational oxidation of a tyrosine residue (Klinman and Mu, 1994). This second group of enzymes (CuAO; E.C.1.4.3.6) contains copper and TPQ; in the Cu-TPQ class, plant enzymes are, in general, more efficient than animal ones, probably because they also function through a radical mechanism which does not operate in the enzymes from animal sources that have been studied (Bellelli et al., 2000).

$\mathrm{CuAO}$ include the subclass of diamine oxidase which preferentially oxidize putrescine, cadaverine, and histamine; indeed, diamine oxidase and histaminase are identical enzymes (Mondovì, 1985). Recently, we have found that a copper amine oxidase (histaminase) purified from the pea seedling has a protective effect on cardiac anaphylactic response in the guinea pig (Masini et al., 2002b). Furthermore, it has been demonstrated that bovine serum $\mathrm{CuAO}$ protects the heart from damage induced by free radical (Mateescu et al., 1997), probably due to an antioxidant effect of this enzyme against oxygen free radicals (Mateescu et al., 1997). Because histamine is a good substrate for the pea seedling enzyme and a crucial mediator in the early phase of allergic bronchospasm (Spina and Page, 2002b), we decided to evaluate the effect of copper diamine oxidase (histaminase) purified from pea seedling as a free or immobilized enzyme on an experimentally induced asthmalike reaction in guinea pig. Repeated exposure of the guinea pig to antigen has been demonstrated to cause airway hyperresponsiveness and leukocyte infiltration of lung tissue, mimicking histological and pharmacological characteristics of asthma in humans (Wanner et al., 1990; Pretolani and Vargaftig, 1993).

\section{Materials and methods}

\subsection{Purification, immobilization, and activity of the enzyme}

Pea seedling histaminase was purified, according to McGuirl et al. (1994), with a specific activity of at least 40 IU (micromoles of substrate oxidized per minute) per milligram protein (one unit being defined as the amount of enzyme catalyzing the oxidation of $1 \mu \mathrm{mol}$ of substrate/ $\mathrm{min})$. The enzyme was used as free enzyme or immobilized on CNBr-Sepharose 6MB (Pharmacia, Uppsala, Sweden) according to Federico et al. (2000).

The enzymatic activity was assayed with histamine $\left(10^{-4} \mathrm{M}\right)$ as substrate, using the fluorimetric method of Matsumoto et al. (1982), in which homovanillic acid is converted into a highly fluorescent compound by the released hydrogen peroxide $\left(\mathrm{H}_{2} \mathrm{O}_{2}\right)$ in the presence of peroxidase. Briefly, the incubation mixture was of the following composition: $0.1 \mathrm{ml}$ of $0.25 \mathrm{M}$ potassium phosphate buffer $(\mathrm{pH} 7.5) ; 0.1 \mathrm{ml}$ of peroxidase $(25,000$ IU) solution $(0.5 \mathrm{mg} / \mathrm{ml}) ; 0.1 \mathrm{ml}$ of homovanillic acid solution $(1 \mathrm{mg} / \mathrm{ml}) ; 0.1 \mathrm{ml}$ of sample (plasma $20 \mathrm{mg} / \mathrm{ml}$, heart $24 \mathrm{mg} / \mathrm{ml}$, lung $23 \mathrm{mg} / \mathrm{ml}$, kidney $21 \mathrm{mg} / \mathrm{ml}$, and liver $24 \mathrm{mg} / \mathrm{ml}$ ); $0.1 \mathrm{ml}$ of histamine $10^{-4} \mathrm{M}$.

The standard curve was prepared with serial concentrations of $\mathrm{H}_{2} \mathrm{O}_{2}$ from 0 to $20 \mathrm{mM}$, and the fluorescence was read at $\lambda_{\text {em }} 426 \mathrm{~nm}$ with $\lambda_{\text {ex }} 324 \mathrm{~nm}$ in a Perkin Elmer $\mathrm{LS}_{50} \mathrm{~B}$ spectrofluorimeter. The protein content was measured by a biuret method (Goa, 1953) using a Perkin Elmer $\lambda 9$ spectrophotometer.

Inactivated histaminase was obtained by the treatment with 10-4 M semicarbazide, inhibitor of all the copperTPQ-dependent amino oxidases. The excess of the inhibitor was dialyzed off, and the activity of the enzyme was checked as above.

\subsection{Animals}

Seventy-six male adult albino guinea pigs, DunkinHartley strain, were used. They were purchased from a commercial dealer (Rodentia, Bergamo, Italy) and quarantined for 7 days at $22-24{ }^{\circ} \mathrm{C}$ on a 12 -h light, 12-h dark cycle before use. Standard laboratory chow (Rodentia), fresh vegetables, and water were available ad libitum.

The experimental protocol was designed to comply with the recommendations of the European Economic Community $(86 / 609 / \mathrm{CEE})$ for the care and use of laboratory animals and was approved by the Animal Care Committee of the University of Florence (Florence, Italy), in agreement with the Good Laboratory Practice Rules. At the end of the treatments, the animals weighed about $350-400 \mathrm{~g}$.

\subsection{Treatments}

Group 1: a group of six guinea pigs was injected with saline [5 ml/kg b.w., intraperitoneally (i.p.), plus $5 \mathrm{ml} / \mathrm{kg}$ 
b.w., subcutaneously (s.c.)]. Two weeks later, these animals were treated with an aerosol of ovalbumin suspended in saline $(5 \mathrm{mg} / \mathrm{ml})$ and used as controls. They are referred to as naïve animals (group 1).

The remaining 70 guinea pigs were sensitized with 100 $\mathrm{mg} / \mathrm{kg}$ b.w., i.p., plus $100 \mathrm{mg} / \mathrm{kg}$ b.w., s.c., ovalbumin, suspended in saline $(20 \mathrm{mg} / \mathrm{ml})$. Two to three weeks later, they were challenged with an aerosol of ovalbumin $(5 \mathrm{mg} /$ $\mathrm{ml}$ in saline) to verify that sensitization had occurred. The animals were withdrawn from antigen exposure at the first sign of respiratory abnormality.

Sixty-eight of 70 guinea pigs developed airway hyperresponsiveness to the inhaled antigen (sensitized animals). They were selected for further treatments, as indicated below.

Group 2: 3 days after ovalbumin challenge, eight guinea pigs were treated with an injection of $0.5 \mathrm{ml}$ of phosphate buffer solution, s.c., $24 \mathrm{~h}$ before a second challenge with ovalbumin aerosol, as above reported.

Groups 3 and 4: 12 guinea pigs were treated as described for group 2, but received an i.p. injection of free histaminase (group 3) or CNBr-Sepharose immobilized histaminase (group 4) at a dose of $20 \mu \mathrm{g}$ in $500 \mu \mathrm{l}$ of PBS $3 \mathrm{~h}$ before a second challenge with ovalbumin aerosol, as above reported.

Groups 5 and 6: 12 guinea pigs were treated as described for group 2, but received an i.p. injection of free histaminase (group 5) or CNBr-Sepharose immobilized histaminase (group 6) at the dose of $20 \mu \mathrm{g}$ in $500 \mu \mathrm{l}$ of buffer, $24 \mathrm{~h}$ before a second challenge with ovalbumin aerosol, as above reported.

Groups 7 and 8: 12 guinea pigs were treated as described for group 2. The animals of group 7 were exposed for 10 min to an aerosol of histaminase immobilized on $\mathrm{CNBr}-$ Sepharose at the dose of $4 \mu \mathrm{g} / \mathrm{ml}$ (flow rate $0.5 \mathrm{ml} / \mathrm{min}$ ). The animals of group 8 were exposed to the second challenge with ovalbumin aerosol in the presence of histaminase immobilized on CNBr-Sepharose at the dose of $4 \mu \mathrm{g} / \mathrm{ml}$.

Two groups of six sensitized guinea pigs and two groups of six naive animals were treated i.p. with $20 \mu \mathrm{g}$ of free or immobilized histaminase to evaluate the concentrations of the enzyme in plasma and in several organs, such as lung, liver, kidney, and heart. Blood samples were obtained at time 0 , and 3, 6, 9, and $18 \mathrm{~h}$ after animal treatment. One-half milliliter of blood, obtained with an intracardiac puncture, was immediately centrifuged to obtain plasma which was frozen at $-20{ }^{\circ} \mathrm{C}$ until use. At $24 \mathrm{~h}$ after enzyme administration, the animals were anesthetized, exsanguinated, and about $300 \mathrm{mg}$ of tissue samples of heart, lungs, kidney, and liver were obtained, washed in saline, and immediately frozen at $-20{ }^{\circ} \mathrm{C}$ until use.

\subsection{Evaluation of respiratory functional parameters}

The guinea pigs of all studied groups were placed, one by one, in a whole body respiratory chamber, as described by
Ballati et al. (1992), Evangelista et al. (1995), and Bani et al. (1997). The changes in inner pressure in the respiratory chamber induced by breathing were monitored with a high sensitivity pressure transducer (Battaglia-Rangoni, Bologna, Italy; pressure and linearity ranges from -10 to $+10 \mathrm{~mm}$ $\mathrm{Hg}$ ) connected to a PC2400A channel of a polygraph (Battaglia-Rangoni). Upon stabilization of the breathing pattern (usually occurring within 30-60 s), the guinea pigs from groups 1-8 were challenged with an aerosol of ovalbumin $(5 \mathrm{mg} / \mathrm{ml}$ in saline) for $10 \mathrm{~s}$. With a Millipore pump, at 5 bar insufflation pressure, very small aerosol particles can be obtained, as assessed in previous tests (Bani et al., 1997). The nonsensitized guinea pigs of group 1 were included in the aerosol challenge to reveal possible alterations in the breathing pattern due to a specific stimulation of the airways by the aerosol droplets. The changes in the respiratory activity of the animals subjected to the different treatments were recorded for 5 min after the aerosol administrations.

The following parameters were evaluated according to Evangelista et al. (1995): (a) latency time, in seconds, for the appearance of the respiratory abnormalities, assessed as the time between the onset of aerosolization and the first cough stroke, a cough stroke being assumed as a respiratory movement whose amplitude exceeded by at least $10 \%$ that of normal breath preceding the cough stroke; (b) cough severity score, assessed as the product of cough frequency and mean cough amplitude, assuming as cough frequency the number of cough strokes per minute and as cough amplitude the excess pressure, in millimeters of $\mathrm{Hg}$, over the normal breath preceding the cough stroke. In addition, (c) occurrence of dyspnea, recognized in breath recordings as a series of irregular breaths of abnormally elevated or reduced amplitude compared with the basal breath, was reported.

To evaluate airway hyperresponsiveness, animals of groups 1, 2, and 4 were exposed to increasing doses of methacholine ( $\mathrm{MeCh}$, Sigma, Milan, Italy), ranging from 2.5 to $50 \mathrm{mg} / \mathrm{ml}$ in saline. Each dose was administered by nebulization for $10 \mathrm{~s}$ in the same respiratory chamber as above with 30-s intervals as previously reported (Park et al., 2001). Three hours before the $\mathrm{MeCh}$ provocation test, the animals from groups 1 to 7 received a second treatment with vehicle, or histaminase, as previously reported. Changes in the respiratory activity of the animals subjected to the $\mathrm{MeCh}$ provocation test were recorded in the same manner as for ovalbumin challenge.

\subsection{Biochemical and morphological analysis}

Thirty minutes after the extraction from the respiratory chamber, the guinea pigs were euthanized by lethal i.p. injections of sodium thiopental (Pentothal, Abbott, Latina, Italy). At death, the thorax was opened to allow the lungs to be examined, and tissue specimens from the middle lobe of the right lung were excised from each animal and processed 
for biochemical determinations, morphometric studies, and light microscopy.

For light microscopic study of lung mast cells, the tissue samples, two from each animal, were fixed by immersion in Mota fluid, dehydrated in graded ethanol, and embedded in paraffin wax. Sections $5 \mu \mathrm{m}$ thick were cut and stained with hematoxylin and eosin for conventional histology and morphometry of lung alveoli and small-sized bronchi or with Astra blue, which selectively binds heparin to reveal metachromasia of mast cell granules. A first series of determinations was carried out on hematoxylin- and eosinstained sections to evaluate the surface area of alveolar aerial spaces. Four randomly chosen microscopical fields per animal (two fields per section) were analyzed. At the chosen magnification, each field corresponds to a tissue area of $570 \mu \mathrm{m}^{2}$ that includes an average of 300 alveolar profiles. The same tissue sections were used to evaluate the surface area of bronchial lumina. Light transmittance across mast cells, which is inversely related to their granule content, was evaluated by a computer-assisted method, as described previously (Masini et al., 1994). The transmission of at least 20 different mast cells chosen at random from animals of the different groups was analyzed, and the mean transmission value $( \pm$ S.E.M.) was then calculated.

Evaluation of luminal area of alveoli and bronchioli in the lung was performed by computer-aided morphometry, according to a method used previously to evaluate the surface area of lung blood vessel (Bani et al., 1997), with minor modifications. Determinations were carried out on hematoxylin- and eosin-stained histological sections, $6 \mu \mathrm{m}$ thick, coming from lung tissue from the different groups. For each experimental group, the mean surface area $( \pm$ S.E.M. $)$ was then calculated.

\subsection{Immunohistochemisty for eosinophil identification}

This was carried out on histological sections, $5 \mu \mathrm{m}$ thick, of Mota-fixed, paraffin-embedded lung tissue fragments. Sections were rehydrated, treated with $0.1 \%$ trypsin for 10 min to retrieve antigen, then with $0.3 \%(\mathrm{v} / \mathrm{v}) \mathrm{H}_{2} \mathrm{O}_{2}$ in $60 \%$ $(\mathrm{v} / \mathrm{v})$ methanol to quench endogenous peroxidase, and, finally, incubated overnight with mouse monoclonal antihuman eosinophil major basic protein (MBP) antibodies (clone BMK13, Chemicon, Temecula, CA; 1:50 in PBS). Immune reaction was revealed by indirect immunoperoxidase method (Vectastain Elite kit, Vector, Burlingame, CA), using 3,3' -diaminobenzidine as chromogen. As negative controls, sections incubated with only the primary or the secondary antisera were used. Observations were carried out with a Reichert-Jung Microstar IV light microscope (Cambridge Instruments, Buffalo, NY). In each guinea pig, the number of MBP-positive eosinophils was counted in 10 randomly chosen microscopical fields at a $\times 200$ final magnification (test area: $72,346 \mu \mathrm{m}^{2}$ ). Values obtained from two different observers were averaged.

\subsection{Determination of lung tissue myeloperoxidase activity}

Myeloperoxidase activity, a hemoprotein located in azurophil granules of neutrophil and eosinophil granulocytes, has been used as a marker for granulocyte accumulation in tissue (Bradley et al., 1982; Mullane et al., 1985). Myeloperoxidase activity was evaluated photometrically according to Bradley et al. (1982). Briefly, frozen lung tissue samples weighing approximately $100 \mathrm{mg}$ were minced and homogenized in $1.5 \mathrm{ml}$ of $50 \mathrm{mM}$ potassium phosphate buffer, $\mathrm{pH}$ 6. One milliliter of the homogenate was centrifuged at $10,000 \times g$ for $10 \mathrm{~min}$, and the pellet was suspended in $1 \mathrm{ml}$ of $150 \mathrm{mM}$ potassium phosphate buffer, $\mathrm{pH} 6$, containing $0.5 \%$ hexa-decyl-trimethyl-ammonium bromide to negate the pseudoperoxidase activity of hemoglobin and to solubilize membrane-bound myeloperoxidase. The suspension was treated with three cycles of freezingthawing, sonicated on ice for $10 \mathrm{~s}$, and centrifuged at $12,000 \times \mathrm{g}$ for $30 \mathrm{~min}$. Myeloperoxidase was determined in the supernatants as previously reported (Griswold et al., 1989). The myeloperoxidase unit was defined as the quantity of enzyme catalyzing $1 \mu \mathrm{mol}$ of substrate with 1 $\mu \mathrm{mol}$ of hydrogen peroxide per minute at $25{ }^{\circ} \mathrm{C}$ and was expressed in milliunits per milligram protein. Protein concentration was determined with the Bradford method (Bradford, 1976).

\subsection{Determination of lung tissue malonyldialdehyde production}

Malonyldialdehyde is an end product of peroxidation of cell membrane lipids and is considered a reliable marker of oxygen-derived free radical damage (Masini et al., 2002a). It was determined by measuring of the chromogen obtained from the reaction of malonyldialdehyde with 2thiobarbituric acid according to Aruoma et al. (1989). Approximately $100 \mathrm{mg}$ of lung tissue was homogenized with $1 \mathrm{ml}$ of $50 \mathrm{mM}$ Tris- $\mathrm{HCl}$ buffer containing $180 \mathrm{mM}$ $\mathrm{KCl}$ and $10 \mathrm{mM}$ EDTA, $\mathrm{pH}$ 7.4, using a tissue homogenizer. A volume of $0.5 \mathrm{ml}$ of 2-thiobarbituric acid

Table 1

Histaminase content in various organs and plasma $(n=6 ; \mathrm{pmol} / \mathrm{mg}$ protein, mean \pm S.E.M.) of sensitized animal treated with free or immobilized enzyme

\begin{tabular}{llc}
\hline Tissues $(18 \mathrm{~h})$ & Free & Immobilized \\
\hline Lung & $60 \pm 10$ & $107 \pm 10$ \\
Liver & $43 \pm 58$ & $112 \pm 14$ \\
Heart & $68 \pm 13$ & $139 \pm 10$ \\
Kidney & $46 \pm 4$ & $83 \pm 20$ \\
& & \\
Plasma & & \\
$0 \mathrm{~h}$ & 0 & 0 \\
$3 \mathrm{~h}$ & $642 \pm 20$ & $272 \pm 5$ \\
$6 \mathrm{~h}$ & $779 \pm 12$ & $90 \pm 8$ \\
$9 \mathrm{~h}$ & $557 \pm 30$ & $39 \pm 18$ \\
$18 \mathrm{~h}$ & $58 \pm 5$ & 0 \\
\hline
\end{tabular}


$(1 \% \mathrm{w} / \mathrm{v}$ in $50 \mathrm{mM} \mathrm{NaOH})$ and $0.5 \mathrm{ml} \mathrm{HCl}(25 \% \mathrm{w} / \mathrm{v}$ in water) were added to $0.5 \mathrm{ml}$ of samples. An aliquot (100 $\mu \mathrm{l})$ of the homogenate was added to a reaction mixture containing $200 \mu \mathrm{l}$ of $8.1 \%(\mathrm{w} / \mathrm{v})$ sodium dodecyl sulphate (SDS), $1500 \mu \mathrm{l}$ of $20 \%$ (w/v) acetic acid (pH 3.5), $1500 \mu \mathrm{l}$ of $0.8 \%(\mathrm{w} / \mathrm{v})$ thiobarbituric acid, and $700 \mu \mathrm{l}$ of distilled water. The mixture was placed in test tubes, sealed with screw caps, and heated in boiling water for $10 \mathrm{~min}$. After cooling, the chromogen was extracted in $3 \mathrm{ml}$ of 1-butanol, and the organic phase was separated by centrifugation at $3000 \times g$ for $10 \mathrm{~min}$. The absorbance of the organic phase was read spectrophotometrically at $600 \mathrm{~nm}$ wavelength. Protein concentration was determined with the Bradford method (Bradford, 1976).

The values were expressed as nanomoles of thiobarbituric acid-reactive substances (malonyldialdehyde equivalence) per milligram protein, using a standard curve of 1,1,3,3-tetramethoxypropane.

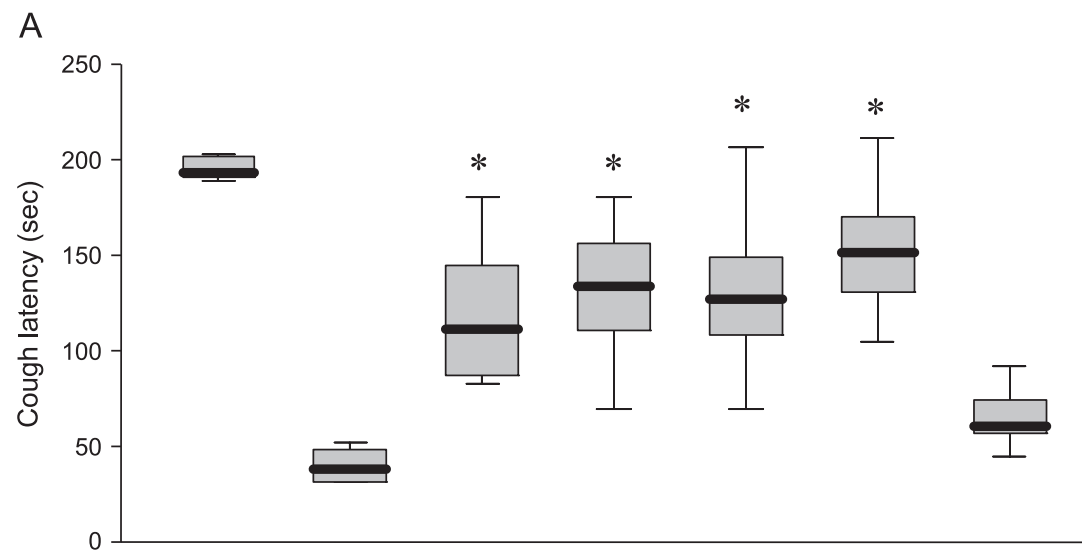

B

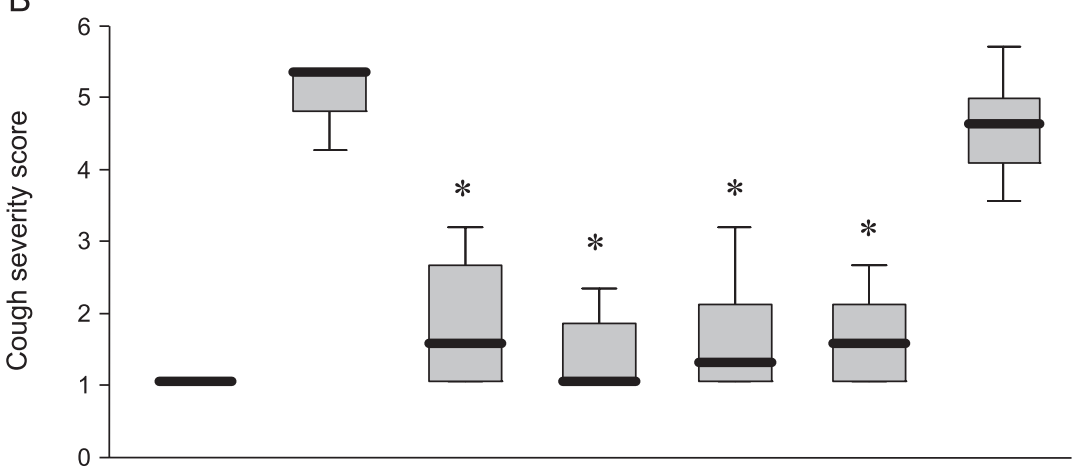

C

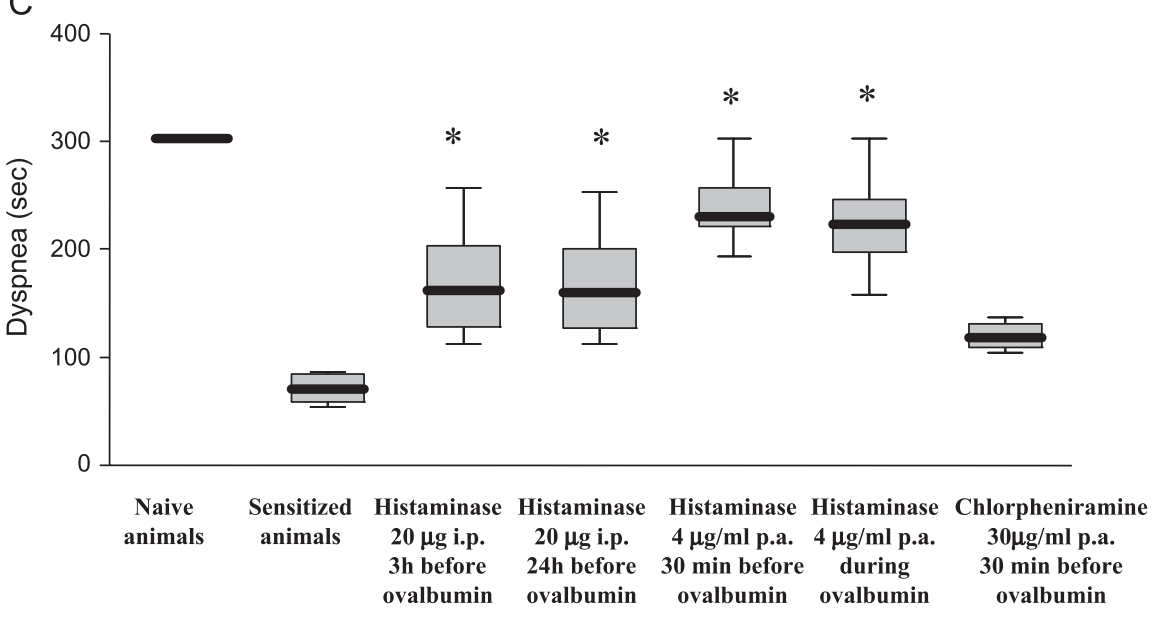

Fig. 1. Effects of CNBr-Sepharose 6MB immobilized histaminase ( $20 \mu \mathrm{g}$ given i.p. 3 or $24 \mathrm{~h}$ before ovalbumin, or $4 \mu \mathrm{g} / \mathrm{ml}$ p.a. $30 \mathrm{~min}$ before ovalbumin or 4 $\mu \mathrm{g} / \mathrm{ml}$ p.a. during ovalbumin challenge) and of chlorpheniramine (30 $\mu \mathrm{g} / \mathrm{ml} \mathrm{p.a.} 30 \mathrm{~min}$ before ovalbumin) on cough latency (A), severity of cough (B), and dyspnea $(\mathrm{C})$ induced by ovalbumin challenge in sensitized guinea pigs. Data are expressed as box plot of 12 experiments; black lines represent median values, boxes represent interquartile ranges, and whiskers represent extreme values. $* P<0.01$ vs. sensitized animals and chlorpheniramine $30 \mu \mathrm{g} / \mathrm{ml} \mathrm{p.a.} 30 \mathrm{~min}$ before ovalbumin. 


\subsection{Materials}

Ovalbumin was obtained from Fluka (Buchs, Switzerland); 3,3' diaminobenzidine tetrahydrochloride, putrescine, homovanillic acid, horseradish peroxidase hexadecyl-trimethylammonium bromide, semicarbazide were obtained from Sigma (St. Louis, MO, USA). CNBr-Sepharose 6MB was obtained from Pharmacia (Central Milton, Keines, UK). All other reagents were used of Suprapur quality for spectroscopy were from Merck (Milan, Italy).

\subsection{Statistical analysis}

The reported data are expressed as the mean \pm S.E.M. of at least 6 independent experiments. Statistical analysis was performed by Kruskal-Wallis $H$ multiple comparison test followed by the Mann-Whitney $U$-test for independent samples. Calculations were carried out using SPSS 11.0.0 (SPSS Inc), with $\mathrm{P}<0.05$ being considered as significant.

\section{Results}

\subsection{Levels of free and immobilized histaminase in plasma and in organs}

The amount of free and immobilized histaminase in lung and liver of sensitized guinea pigs after an injection of 20 $\mu \mathrm{g}$, i.p., corresponding to a specific activity of $40 \mathrm{IU} \mathrm{mg} \mathrm{m}^{-1}$ protein of both enzymes is reported in Table 1. In the plasma and lung of naive animals, no detectable histaminase activity was found. The histaminase activity in plasma, lung, and liver in the sensitized animals treated with free and immobilized enzyme was high at 3-6 h and decreased later. In the group of the sensitized guinea pigs, the values of enzymatic activity in lung, liver, and heart were twice as high in the animals treated with immobilized enzyme as in those treated with the free form (Table 1).

\subsection{Respiratory functional parameters}

The median values of the respiratory parameters are reported in Fig. 1. There were no substantial abnormalities in the nonsensitized guinea pigs (naive animals, group 1) after inhalation of an aerosol of ovalbumin $(5 \mathrm{mg} / \mathrm{ml})$, except for some sporadic cough strokes arising about 2-3 min after the onset of the aerosol treatment.

Challenge of sensitized guinea pigs (group 2) with ovalbumin aerosol resulted in evident abnormalities in the respiratory pattern, consisting in a significant reduction of cough latency time (Fig. 1A), a significant increase in the severity of cough (Fig. 1B), and in the occurrence of episodes of dyspnea in the breath recordings (Fig. 1C). Conversely, the treatment of the animals with free or $\mathrm{CNBr}$ Sepharose 6MB immobilized histaminase at the dose of 20 $\mu \mathrm{g}$, i.p., 3 or $24 \mathrm{~h}$ before ovalbumin aerosol or per aerosol at the dose of $4 \mu \mathrm{g} 30 \mathrm{~min}$ before or during ovalbumin challenge with a rate of $1 \mathrm{ml} / \mathrm{min}$ for $5 \mathrm{~min}$ (corresponding to a total dose of $0.8 \mathrm{IU}$ ), resulted in a significant reduction in respiratory abnormalities compared with those presented in the animals of group 2 receiving the administration of buffered saline. In particular, the cough latency time was significantly increased (Fig. 1A), and the severity of cough was significantly reduced (Fig. 1B) upon administration of free or immobilized histaminase i.p. or per aerosol. The clearcut signs of dyspnea in the breath recordings of the animals treated with histaminase were significantly delayed and less severe than in the group of untreated ones (Fig. 1C). The maximal protective effect in delaying the appearance of respiratory abnormalities or in decreasing the cough severity was observed when the enzyme was given per aerosol together with ovalbumin challenge (Fig.

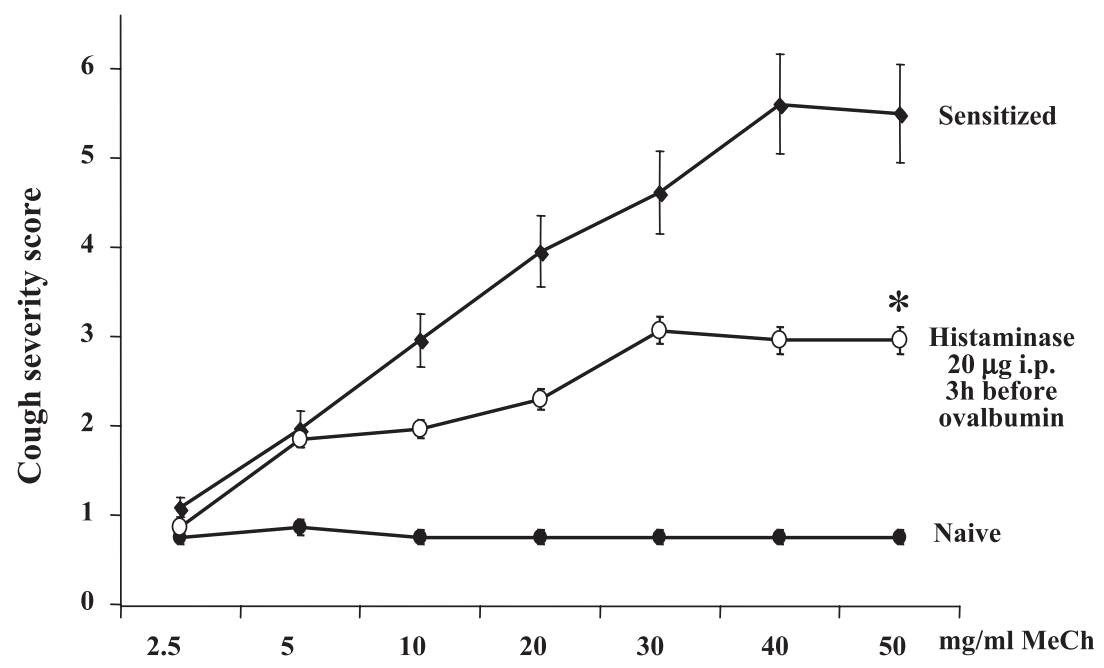

Fig. 2. Effect of CNBr-Sepharose 6MB immobilized histaminase ( $20 \mu \mathrm{g}$ given i.p. $3 \mathrm{~h}$ before ovalbumin) on severity of cough induced by increasing concentrations of $\mathrm{MeCh}$ in sensitized guinea pigs. Comparison with untreated sensitized and naive animals. Data are expressed as mean \pm S.E.M. of eight experiments. ${ }^{*} P<0.01$ vs. sensitized animals. 


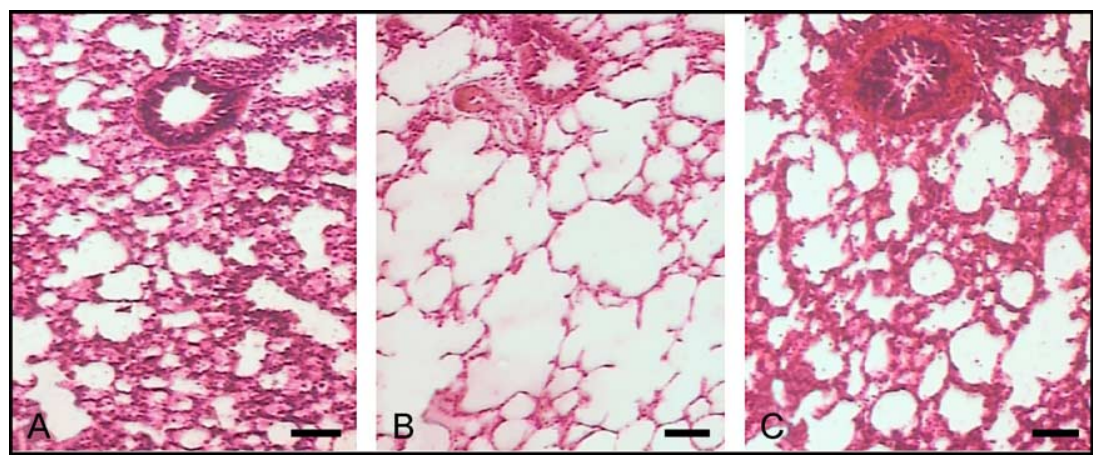

Fig. 3. Representative light micrographs of lung tissue from guinea pigs of the different experimental groups. Compared to the nonsensitized controls (A), in the sensitized animals undergoing ovalbumin aerosol (B), a clearcut dilation of alveolar aerial spaces and constriction of small-sized muscular bronchi can be observed. These alterations are prevented by histaminase pretreatment before ovalbumin challenge $(\mathrm{C})$. Hematoxylin and eosin staining; bars=100 $\mu \mathrm{m}$.

1). Semicarbazide inactivated histaminase was completely ineffective on all the functional parameters examined (data not reported).

The results of the respiratory parameters after the metacholine provocation test are reported in Fig. 2. Histaminase determined a significant $(p<0.01)$ reduction in airway hyperresponsiveness evaluated as cough severity score (Fig. 2).

\subsection{Morphology and morphometry of lung, bronchi, and mast cells after ovalbumin challenge}

\subsubsection{Morphology}

Macroscopic examination of the lungs showed prominent changes in the sensitized guinea pigs challenged with the antigen (group 2) compared with the nonsensitized guinea pigs (group 1) or the sensitized animals not exposed to aerosol. These changes mainly consisted in marked swelling of the pulmonary lobes due to air accumulation. The section of trachea or of main bronchi did not cause lung deflation, thus indicating that peripheral airway obstruction had occurred. Lung inflation was not observed in all sensitized guinea pig groups treated with histaminase (groups 3-8). Light microscopy of lung tissue showed that the intrapulmonary bronchi and respiratory air space of control guinea pigs in group 1 had a normal appearance. In particular, intrapulmonary bronchi showed open lumina with bronchial mucosa forming short folds, and the respiratory air spaces were small (Fig. 3A). On the contrary, lung tissue from the sensitized guinea pigs challenged with the antigen (group 2) showed a reduction of the intrapulmonary bronchial lumen. In large areas of the lung parenchyma, the respiratory air spaces were markedly dilated by accumulation of trapped air (Fig. 3B). In sensitized guinea pigs treated with histaminase, the histology and abnormalities following ovalbumin-induced reaction were nearly abrogated. In fact, the intrapulmonary bronchi usually showed no appreciable signs of constriction, and the respiratory air spaces were not dilated (Fig. 3C). Attenuated signs of bronchoconstriction and dilation of respiratory air spaces were observed only in small areas of lung parenchyma. Histaminase alone, without sensitizing and/or treating with ovalbumin, was completely ineffective (data not shown).

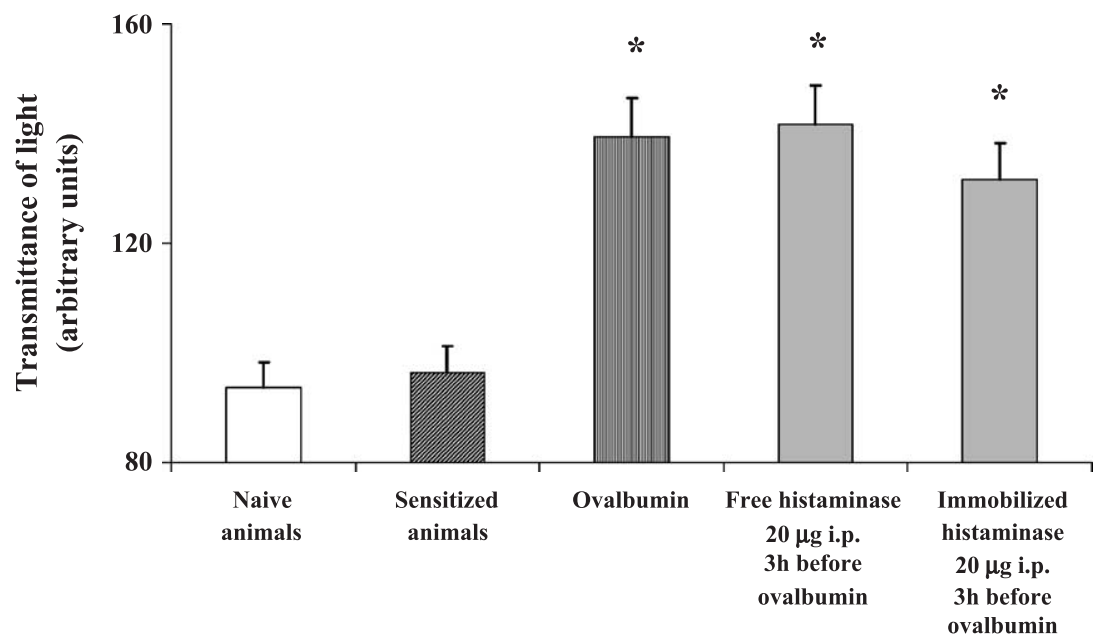

Fig. 4. Mast cell metachromatic granule content, measured as increased light transmittance. Optical density of mast cells from lungs of naive animals, sensitized animals, sensitized animals after ovalbumin challenge, and from sensitized animals pretreated with free or immobilized histaminase (20 $\mu \mathrm{g}$, i.p.) $3 \mathrm{~h}$ before ovalbumin challenge. Data are expressed as mean \pm S.E.M. of 12 experiments. $* P<0.01$ vs. sensitized animals. 


\subsubsection{Morphometry}

Mast cell densitometry revealed a significant increase in light transmittance, indicating a decrease in the metachromatic granule content of the cells, in mast cells from sensitized guinea pigs challenged with ovalbumin (group 2) compared with those in the control, unsensitized animals of group 1. In mast cells of the sensitized guinea pigs, treated i.p. $3 \mathrm{~h}$ before ovalbumin challenge both with $20 \mu \mathrm{g}$ of free or immobilized histaminase, the light transmittance was not modified in comparison to the values obtained in the sensitized animals challenged with ovalbumin and treated with vehicle (Fig. 4). These results clearly indicate that histaminase did not produce any chromoglycate-like effect on antigen-induced degranulation of lung mast cells.

The morphometric analysis of the luminal area of alveoli in guinea pigs treated with histaminase was significantly reduced $(P<0.001)$ when compared to the buffered saline- treated group (Fig. 5A); meanwhile, the luminal area of lung peripheral bronchi was also significantly $(P<0.001)$ increased in guinea pigs treated with histaminase (Fig. 5B). These results clearly indicate that the treatment of the guinea pigs with histaminase results in a significant bronchodilation, as shown by increasing the luminal area of bronchi and decreasing air accumulation in the alveoli.

\subsection{Leukocyte infiltration and lipid peroxidation in lung tissue}

Detection of MBP-positive eosinophils showed almost no cells in the unsensitized guinea pigs, whereas a few scattered positive cells could be observed in the sensitized, not challenged animals. Immunostained cells increased markedly in the sensitized, ovalbumin-challenged guinea pigs. They were mostly located in the inflammatory
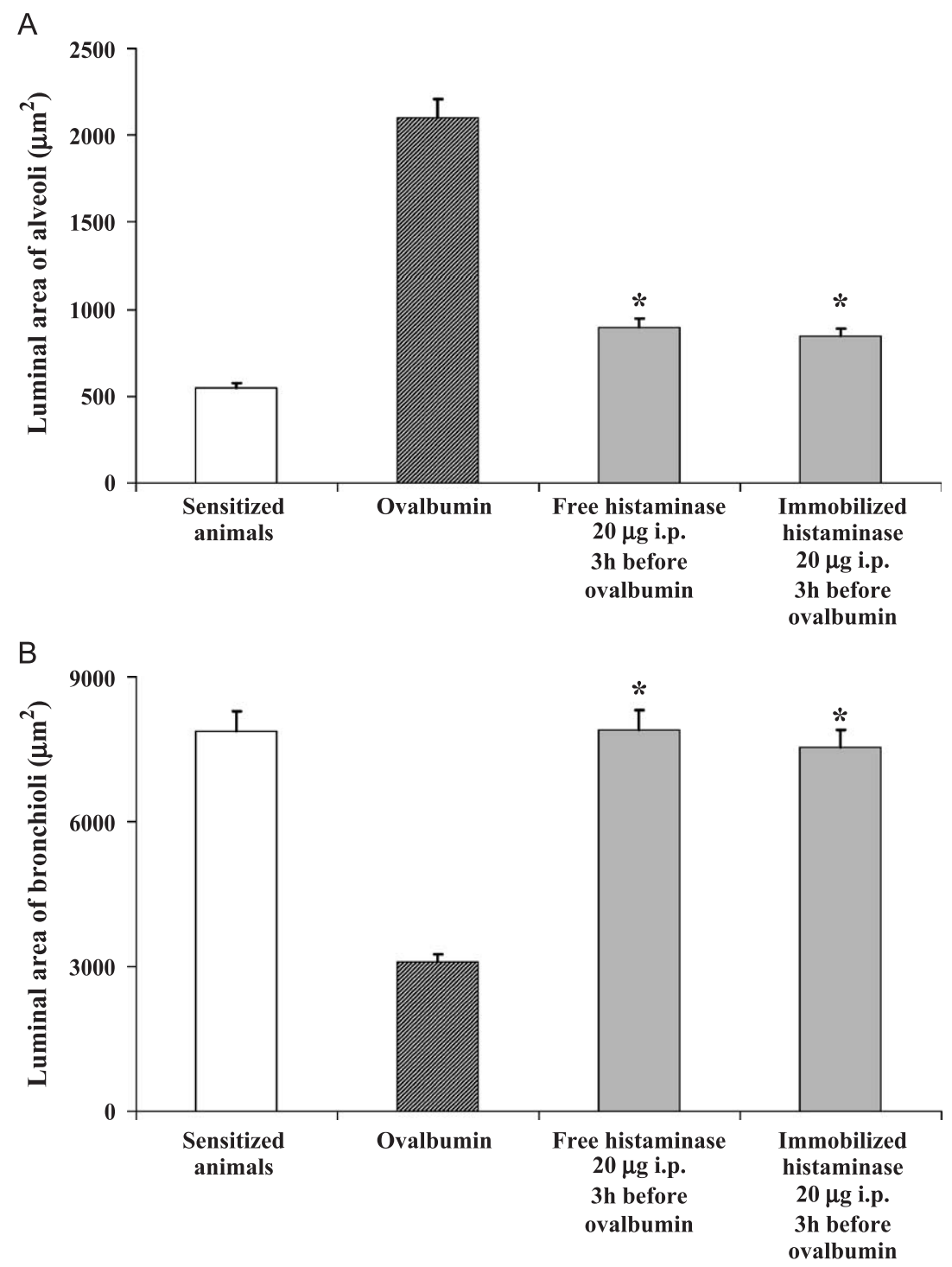

Fig. 5. Morphometric analysis of luminal area of alveoli (A) and luminal area of bronchioli (B). Quantification of the effects on lung architecture obtained from sensitized animals, sensitized animals after ovalbumin challenge, and from sensitized animals pretreated with free or immobilized histaminase (20 $\mu \mathrm{g}$, i.p.) $3 \mathrm{~h}$ before ovalbumin challenge. Data are expressed as mean \pm S.E.M. of 12 experiments. ${ }^{*} P<0.01$ vs. ovalbumin. 


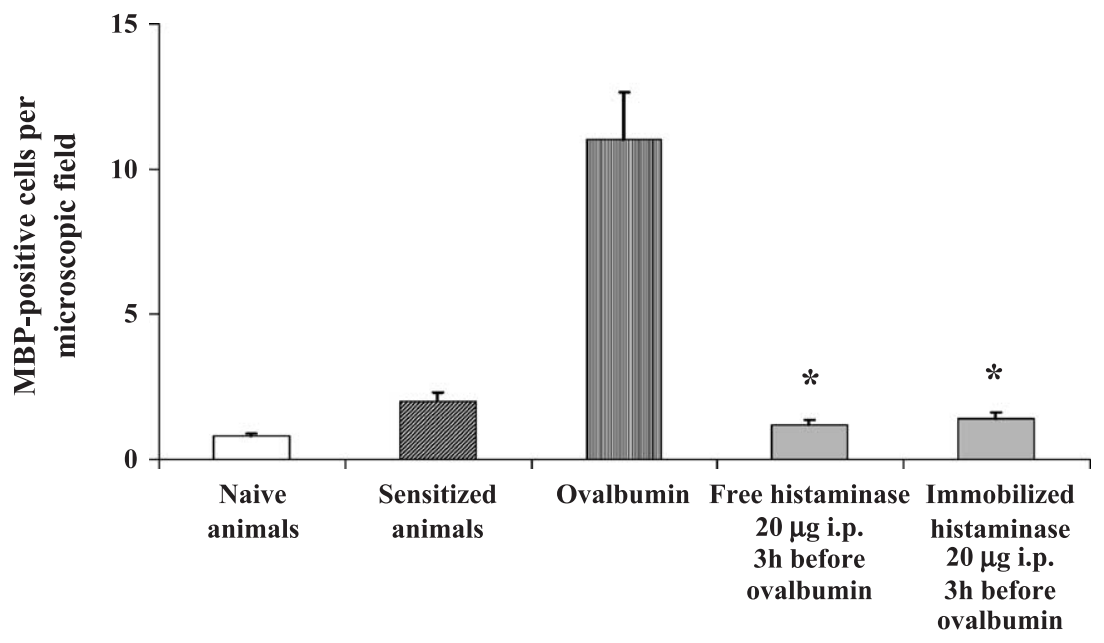

Fig. 6. Effects of free or immobilized histaminase ( $20 \mu \mathrm{g}$, i.p., $3 \mathrm{~h}$ before ovalbumin) on the amount of MBP-immunoreactive lung eosinophils in lung tissue obtained from naïve animals, sensitized animals, sensitized animals after ovalbumin challenge, and from sensitized animals pretreated with free or immobilized histaminase ( $20 \mu \mathrm{g}$, i.p., $3 \mathrm{~h}$ before ovalbumin challenge). Data are expressed as mean \pm S.E.M. of 12 experiments. $* P<0.01$ vs. ovalbumin.

infiltrate surrounding the bronchi and within the stromal septa. In the sensitized, ovalbumin-challenged guinea pigs pretreated with histaminase, immunostained cells were markedly reduced, thus attaining values similar to the unsensitized controls (Fig. 6).

Furthermore, myeloperoxidase activity, a marker of leukocyte infiltration into inflamed tissues, underwent a marked, significant increase in the sensitized guinea pigs challenged with ovalbumin (group 2) compared with naïve animals (group 1) as (Fig. 7). Both free and immobilized histaminase significantly decreased $(P<0.001)$ the activity of myeloperoxidase in lung tissue.

It is well known that malonyldialdehyde production, measured as equivalent of thiobarbituric acid, is a suitable index of membrane lipid peroxidation and cell damage (Rao et al., 1983). In our experiments, antigen challenge in sensitized guinea pigs of group 2 produced a significant increase in malonyldialdehyde production in comparison to naive animals of group 1 . In lungs from animals treated with both free or immobilized histaminases, a significant decrease in malonyldialdehyde production took place at a level comparable to that of unsensitized animals of group 1 (Fig. 8). No differences in potency were noted between free or immobilized histaminases.

\section{Discussion}

The results of this study indicate that two forms (free and immobilized) of pea seedling histaminase counteract the pulmonary asthmalike response to inhaled antigen in sensitized guinea pigs, as well as the increased responsive-

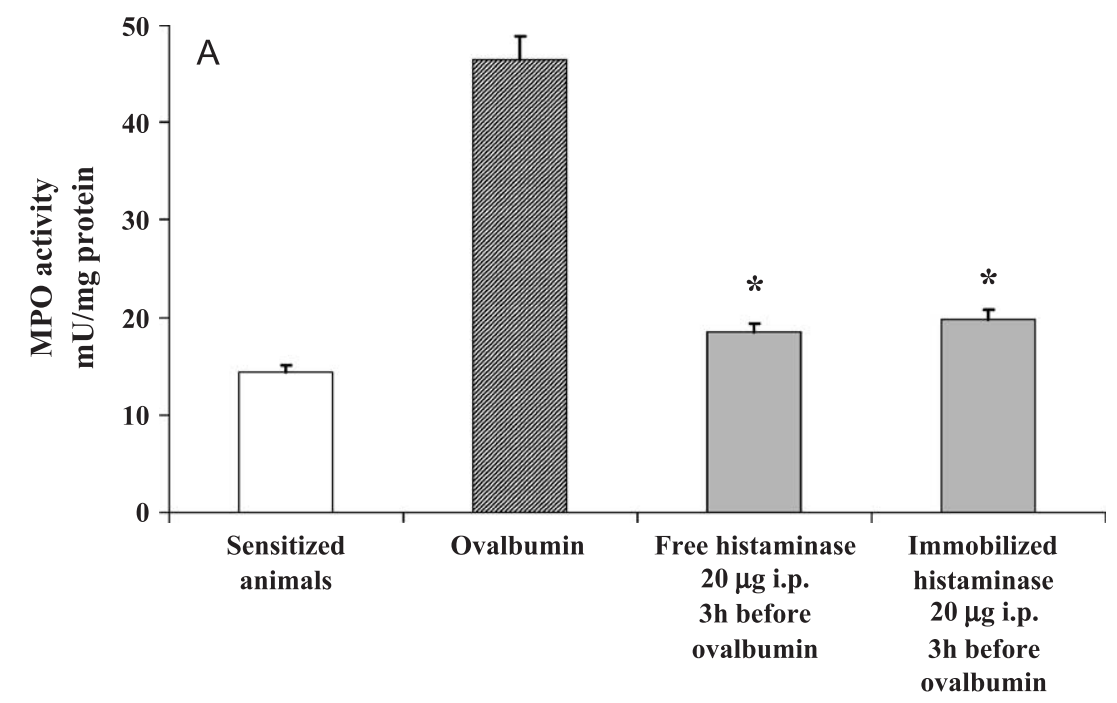

Fig. 7. Effects of free or immobilized histaminase (20 $\mu$ g, i.p., $3 \mathrm{~h}$ before ovalbumin) on myeloperoxidase (MPO) activity in lung tissue obtained from sensitized animals, sensitized animals after ovalbumin challenge, and from sensitized animals pretreated with free or immobilized histaminase ( $20 \mu \mathrm{g}$, i.p.) $3 \mathrm{~h}$ before ovalbumin challenge. Data are expressed as mean \pm S.E.M. of 12 experiments. $* P<0.01$ vs. ovalbumin. 


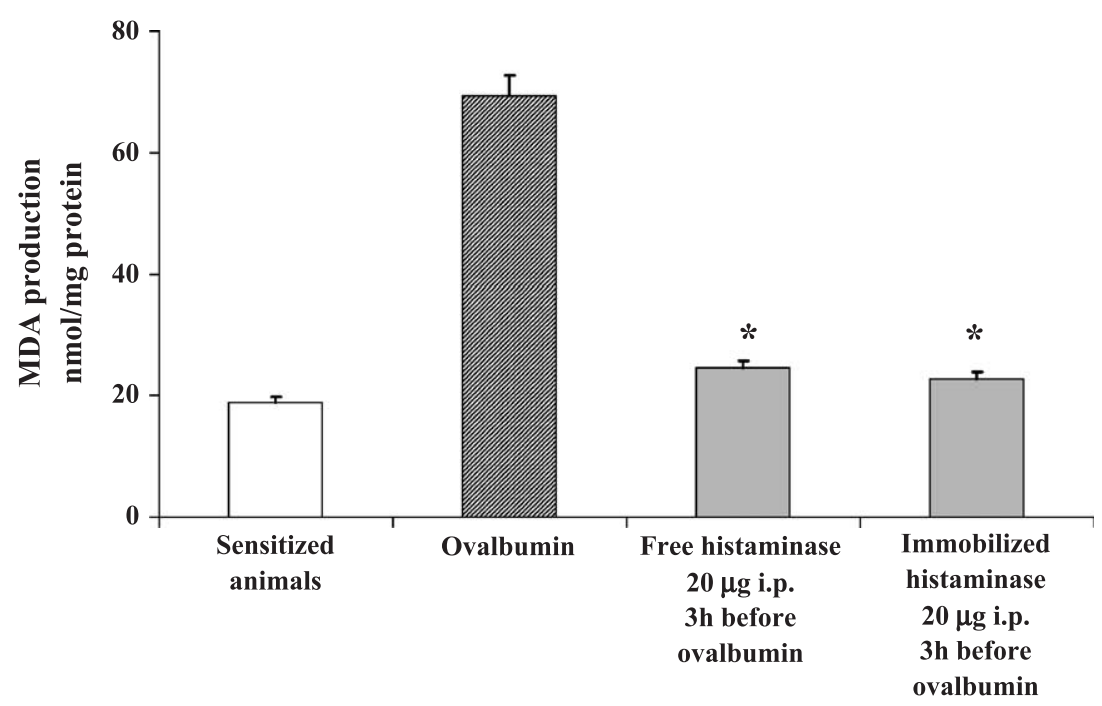

Fig. 8. Effects of free or immobilized histaminase ( $20 \mu \mathrm{g}$, i.p., $3 \mathrm{~h}$ before ovalbumin) on malonyldialdehyde (MDA) production in lung tissue obtained from sensitized animals, sensitized animals after ovalbumin challenge, and from sensitized animals pretreated with free or immobilized histaminase ( $20 \mu \mathrm{g}$, i.p.) $3 \mathrm{~h}$ before ovalbumin challenge. Data are expressed as mean \pm S.E.M. of 12 experiments. $* P<0.01$ vs. ovalbumin.

ness to nonspecific stimuli, as shown by the methacholine provocation test. An evaluation of the respiratory activity of sensitized guinea pigs shows that treatment with histaminase nearly eliminates the breathing abnormalities typical of airway hyperresponsiveness to the inhaled antigen.

This effect of pea seedling histaminase is accompanied by a marked reduction in the histological signs of lung injury in response to antigen challenge, such as bronchial constriction, dilation of respiratory air spaces, leukocyte infiltration, and lipid peroxidation. The mechanisms by which histaminase exerts its beneficial action probably rely on the inactivation of histamine released by resident mast cells afforded by the enzyme.

It was surprising that higher amounts of histaminase were found in lung, liver, and heart when the immobilized form was administered. The distribution of this conjugate via the circulation can be explained by the fact that the support used, CNBr-activated agarose (CNBr-Sepharose $6 \mathrm{MB}$ ), was not cross-linked and thus tends to melt at body temperature. The distribution of the conjugate in various organs may be facilitated by the galactose units present in the structure of agarose supports: the uncross-linked agarose exhibiting galactose units can be retained by carbohydrate-binding proteins in organs and tissues, and thus the plasma concentration appears lower. The conjugate of histaminase with the activated Sepharose presents several advantages. The most important is that this support is an uncross-linked agarose, which when administered will first become soft and then can even melt, allowing the uptake by cells or a deeper interaction with membranes. Furthermore, the enzyme conjugate with agarose was shown to be more stable at proteolysis or denaturing factors (Federico et al., 2000). The behavior of histaminase-agarose conjugates can prefigure the use of other polymeric conjugates of this therapeutic enzyme.
Histamine and superoxide anion are released from lung mast cells after antigen challenge. These mediators are responsible for bronchoconstriction, vessel edema and neutrophil, and eosinophil recruitment from the circulation to the lung, as indicated by the presence of degranulated mast cells (Bani et al., 1997; O'Sullivan et al., 1998; Brightling et al., 2002) and by the increase in myeloperoxidase activity, a marker of granulocyte accumulation in tissue (Bradley et al., 1982) after antigen challenge.

Pea seedling histaminase has been shown to strongly decrease eosinophil and neutrophil leukocyte recruitment, both through the oxidation of histamine and the scavenging of free radicals, two elements which are known to promote neutrophil and eosinophil chemotaxis (O'Sullivan et al., 1998; Brightling et al., 2002). This effect is evidenced by the decreased myeloperoxidase activity and the low number of MBP-immunoreactive eosinophils in the inflammatory infiltrate surrounding the bronchi in histaminase-treated guinea pigs. In turn, neither free nor immobilized histaminase modified the increase in light transmission through lung mast cells in response to antigen, meaning that the two forms of enzyme do not produce any cytoprotective membrane stabilizing chromoglycate-like effect on the antigen-evoked degranulation of mast cells.

It was previously shown that copper proteins, such as ceruloplasmin (Chahine et al., 1991; Mateescu et al., 1995; Atanasiu et al., 1998) and serum aminoxidase (Mateescu et al., 1997; Mondovi et al., 1997), exhibit a powerful antioxidant capacity, stronger than that of known antioxidant agents, such as deferoxamine (Atanasiu et al., 1995) and superoxide dismutase (Dumoulin et al., 1996), and that this antioxidant activity does not seem to be related to the enzymatic activities of these copper oxidases. It is therefore likely that copper histaminase exerts similar antioxidant capacities. In fact, histaminase was recently shown 
(Masini et al., 2003) to protect the rat against ischemiaand reperfusion-induced oxidative damage, with a cardioprotective pattern similar to that of ceruloplasmin (Atanasiu et al., 1995) and of serum amineoxidase (Mondovi et al., 1997).

The enzyme does not seem to act through the blockade of $\mathrm{H}_{1}$ receptors. Classical antihistamines are in fact scarcely effective in preventing granulocyte recruitment (Townley, 1992; Eda et al., 1994), and, as shown in Fig. 1, the classic $\mathrm{H}_{1}$ blocker chlorpheniramine $(30 \mu \mathrm{g} / \mathrm{ml}$ p.a. $30 \mathrm{~min}$ before antigen challenge) is significantly less effective than histaminase in the prevention of asthmalike reactions.

Histaminase has also been shown to strongly decrease the production of malonyldialdehyde, a lipid peroxidation metabolite, in lungs from guinea pigs exposed to ovalbumin aerosol. This finding clearly indicates that pea seedling histaminase is able to reduce peroxidation of cell membrane lipids induced by oxygen-derived free radicals generated during antigen-induced bronchospasm (Calhoun et al., 1992), thus offering protection to cells that could be damaged by them.

In this sense, it has recently been shown that bovine serum amine oxidases exert an in vitro antioxidant effect on electrolysis-induced oxidative species and an ex vivo cardioprotective action on oxidative injury in isolated rat heart (Mateescu et al., 1997), and these effects are similar to those of cardioprotective and antioxidant drugs, such as mannitol or desferoxamine (Mateescu et al., 1997).

It is well known that, besides histamine, reactive oxygen species play a key role in allergic asthma and other inflammatory lung diseases (Eiserich et al., 1998; de Boer et al., 2001). These species are cytotoxic because they induce cellular oxidative stress, which can cause cellular dysfunction, damage, and, eventually, cell death. Several reports have shown that inflammatory cells produce large amounts of superoxide anions in asthma attacks and that an inverse correlation exists between neutrophil infiltration, superoxide production, and airway obstruction (Jarjour and Calhoun, 1994). In our previous report (Masini et al., 2002b), we demonstrate protection by pea seedling histaminase against cardiac anaphylactic shock, owing to decreased anaphylactic release of histamine in the treated animals. Altogether, our results show that histaminase can reduce the infiltration of neutrophils into lung tissue, lipid peroxidation, and acute bronchospastic reaction and strongly suggest that this plant histaminase may be useful in the treatment of allergic diseases.

\section{Acknowledgements}

This research was supported by grants from the Ministry of University and Scientific and Technologic Research and University of Florence, Rome 3 and Rome "La Sapienza". We are grateful to Prof. Daniele Bani, Department of Anatomy, Histology, and Forensic Medicine, Section of
Histology, University of Florence, for the morphometric analysis and to Ms. Mary Forrest for language correction. Patent RM2000 A000626 and 2469PTWO pending.

\section{References}

Aruoma, O.I., Halliwell, B., Laughton, M.J., Quinlan, G.J., Gutteridge, J.M., 1989. The mechanism of initiation of lipid peroxidation. Evidence against a requirement for an iron (II)-iron(III) complex. Biochem. J. $258,617-620$.

Atanasiu, R., Dumoulin, M.J., Chahine, R., Mateescu, M.A., Nadeau, R., 1995. The antiarrhythmic effects of ceruloplasmin during reperfusion in the ischemic isolated rat heart. Can. J. Physiol. Pharm. 73, 1253-1261.

Atanasiu, R., Stea, D., Mateescu, M.A., Vergely, C., Dalloz, F., Maupoil, V., Nadeau, R., Rochette, L., 1998. Direct evidence of ceruloplasmin free radicals scavenging properties. Mol. Cell. Biochem. 189, 127-135.

Ballati, L., Evangelista, S., Maggi, C.A., Manzini, S., 1992. Effects of selective tachykinin receptor antagonists on capsaicin- and tachykinininduced bronchospasm in anaesthetized guinea-pigs. Eur. J. Pharmacol. 214, 215-221.

Bani, D., Ballati, L., Masini, E., Bigazzi, M., Sacchi, T.B., 1997. Relaxin counteracts asthma-like reaction induced by inhaled antigen in sensitized guinea-pigs. Endocrinology 138, 1909-1915.

Bellelli, A., Morpurgo, L., Mondovi, B., Agostinelli, E., 2000. The oxidation and reduction reactions of bovine serum amine oxidase. A kinetic study. Eur. J. Biochem. 267, 3264-3269.

Bradding, P., Holgate, S.T., 1996. The mast cell as a source of cytokines in asthma. Ann. N.Y. Acad. Sci. 796, 272-281.

Bradford, M.M., 1976. A rapid and sensitive method for the quantitation of microgram quantities of protein utilizing the principle of protein-dye binding. Anal. Biochem. 72, 248-254.

Bradley, P.P., Christensen, R.D., Rothstein, G., 1982. Cellular and extracellular myeloperoxidase in pyogenic inflammation. Blood 60 , $618-622$.

Brightling, C.E., Bradding, P., Symon, F.A., Holgate, S.T., Wardlaw, A.J., Pavord, I.D., 2002. Mast-cell infiltration of airway smooth muscle in asthma. N. Engl. J. Med. 346, 1699-1705.

Calhoun, W.J., Reed, H.E., Moest, D.R., Stevens, C.A., 1992. Enhanced superoxide production by alveolar macrophages and air-space cells, airway inflammation, and alveolar macrophage density changes after segmental antigen bronchoprovocation in allergic subjects. Am. Rev. Respir. Dis. 145, 317-325.

Chahine, R., Mateescu, M.A., Roger, S., Yamaguchi, N., De Champlain, J., Nadeau, R., 1991. Protective effect of ceruloplasmin against electrolysis-induced oxygen free radicals in rat heart. Can. J. Physiol. Pharm. 69, $1459-1464$.

Comhair, S.A., Lewis, M.J., Bhathena, P.R., Hammel, J.P., Erzurum, S.C., 1999. Increased glutathione and glutathione peroxidase in lungs of individuals with chronic beryllium disease. Am. J. Respir. Crit. Care Med. 159, 1824-1829.

de Boer, J., Meurs, H., Flendrig, L., Koopal, M., Zaagsma, J., 2001. Role of nitric oxide and superoxide in allergen-induced airway hyperreactivity after the late asthmatic reaction in guinea-pigs. Br. J. Pharmacol. 133, $1235-1242$.

Drazen, J.M., 1999. Asthma therapy with agents preventing leukotriene synthesis or action. Proc. Assoc. Am. Physicians 111, 547-559.

Dumoulin, M.J., Chahine, R., Atanasiu, R., Nadeau, R., Mateescu, M.A., 1996. Comparative cardioprotective and antioxidant properties ceruloplasmin, superoxide dismutase and bovine serum albumin. Arzneim.Forsch./Drug Res. 46, 855-861.

Eda, R., Townley, R.G., Hopp, R.J., 1994. Effect of terfenadine on human eosinophil and neutrophil chemotactic response and generation of superoxide. Ann. Allergy 73, 154-160.

Eiserich, J.P., Hristova, M., Cross, C.E., Jones, A.D., Freeman, B.A., Halliwell, B., van, d., V., 1998. Formation of nitric oxide-derived 
inflammatory oxidants by myeloperoxidase in neutrophils. Nature 391, 393-397.

Evangelista, S., Ballati, L., Boni, P., Castellucci, A., Perretti, F., Tramontana, M., Toja, E., 1995. Pharmacodynamic profile of the new potent antibronchospastic agent 7-[(2,2-dimethyl)propyl]-1-methyl xanthine. Arzneim.-Forsch./Drug Res. 45, 569-575.

Federico, R., Befani, O., Mondovi, B., Mulhbacher, J., Mateescu, M.A., 2000. Immobilization of plant histaminase for medical applications. Inflamm. Res. 49 (Suppl. 1), S60-S61.

Galli, S.J., 1993. New concepts about the mast cell. N. Engl. J. Med. 328, $257-265$.

Goa, J.A., 1953. Microbiuret method for protein determination: a determination of total protein in cerebrospinal fluid. Scand. J. Clin. Invest. 5, 218-222.

Griswold, D.E., Hillegass, L., Hill, D.E., Sherief, H.T., Kopia, G.A., 1989. Evaluation of the effect of Evan's blue and triphenyltetrazolium chloride dyes on myeloperoxidase activity in canine cardiac tissue. J. Pharmacol. Methods 21, 13-19.

Hartert, T.V., Peebles Jr., R.S., 2000. Epidemiology of asthma: the year in review. Curr. Opin. Pulm. Med. 6, 4-9.

Jarjour, N.N., Calhoun, W.J., 1994. Enhanced production of oxygen radicals in asthma. J. Lab. Clin. Med. 123, 131-136.

Klinman, J.P., Mu, D., 1994. Quinoenzymes in biology. Annu. Rev. Biochem. 63, 299-344.

Masini, E., Bani, D., Bigazzi, M., Mannaioni, P.F., Bani-Sacchi, T., 1994. Effects of relaxin on mast cells. In vitro and in vivo studies in rats and guinea-pigs. J. Clin. Invest. 94, 1974-1980.

Masini, E., Cuzzocrea, S., Mazzon, E., Marzocca, C., Mannaioni, P.F., Salvemini, D., 2002a. Protective effects of M40403, a selective superoxide dismutase mimetic, in myocardial ischaemia and reperfusion injury in vivo. Br. J. Pharmacol. 136, 905-917.

Masini, E., Vannacci, A., Marzocca, C., Mannaioni, P.F., Befani, O., Federico, R., Toma, A., Mondovi, B., 2002b. A plant histaminase modulates cardiac anaphylactic response in guinea-pig. Biochem. Biophys. Res. Commun. 296, 840-846.

Masini, E., Pierpaoli, S., Marzocca, C., Mannaioni, P.F., Pietrangeli, P., Mateescu, M.A., Zelli, M., Federico, R., Mondavi, B., 2003. Protective effects of a plant histaminase in myocardial ischaemia and reperfusion injury in vivo. Biochem. Biophys. Res. Commun. 309, 432-439.

Mateescu, M.A, Chahine, R., Roger, S., Atanasiu, R., Yamaguchi, N., Lalumière, G., Nadeau, R., 1995. Protection of myocardial tissue against the deleterious effects of oxygen free radicals by ceruloplasmin. Arzneim.-Forsch./Drug Res. 45, 476-480.

Mateescu, M.A., Dumoulin, M.J., Wang, X.T., Nadeau, R., Mondovi, B., 1997. A new physiological role of copper amine oxidases: cardioprotection against reactive oxygen intermediates. J. Physiol. Pharmacol. 48, $110-121$

Matsumoto, T., Furuta, T., Nimura, Y., Suzuki, O., 1982. Increased sensitivity of the fluorometric method of Snyder and Hendley for oxidase assays. Biochem. Pharmacol. 31, 2207-2209.
McGuirl, M.A., McCahon, C.D., McKeown, K.A., Dooley, D.M., 1994. Purification and characterization of pea seedling amine oxidase for crystallization studies. Plant Physiol. 106, 1205-1211.

Mondovì, B., 1985. Structure and Functions of Amine Oxidases. CRC Press, Boca Raton, FL.

Mondovi, B., Riccio, P., Agostinelli, E., 1988. The biological functions of amine oxidases and their reaction products: an overview. Adv. Exp. Med. Biol. 250, 147-161.

Mondovi, B., Wang, X.T., Pietrangeli, P., Wang, R., Nadeau, R., Mateescu, M.A., 1997. New aspects on the physiological role of copper amineoxidases. Curr. Top. Med. Chem. 2, 31-43.

Mullane, K.M., Kraemer, R., Smith, B., 1985. Myeloperoxidase activity as a quantitative assessment of neutrophil infiltration into ischemic myocardium. J. Pharmacol. Methods 14, 157-167.

Myers, T.R., 2000. Pediatric asthma epidemiology: incidence, morbidity, and mortality. Respir. Care Clin. N. Am. 6, 1-14.

O'Sullivan, S., Roquet, A., Dahlen, B., Larsen, F., Eklund, A., Kumlin, M., O’Byrne, P.M., Dahlen, S.E., 1998. Evidence for mast cell activation during exercise-induced bronchoconstriction. Eur. Respir. J. $12,345-350$.

Page, S., Ammit, A.J., Black, J.L., Armour, C.L., 2001. Human mast cell and airway smooth muscle cell interactions: implications for asthma. Am. J. Physiol., Lung Cell. Mol. Physiol. 281, L1313-L1323.

Park, Y., Chang, Y.S., Lee, S.W., Cho, S.Y., Kim, Y.K., Min, K.U., Kim, Y.Y., Cho, S.H., Sung, Y.C., 2001. The enhanced effect of a hexameric deoxyriboguanosine run conjugation to $\mathrm{CpG}$ oligodeoxynucleotides on protection against allergic asthma. J. Allergy Clin. Immunol. 108, 570-576.

Pretolani, M., Vargaftig, B.B., 1993. From lung hypersensitivity to bronchial hyperreactivity. What can we learn from studies on animal models? Biochem. Pharmacol. 45, 791-800.

Rao, P.S., Cohen, M.V., Mueller, H.S., 1983. Production of free radicals and lipid peroxides in early experimental myocardial ischemia. J. Mol. Cell. Cardiol. 15, 713-716.

Rossi, G.L., Olivieri, D., 1997. Does the mast cell still have a key role in asthma? Chest $112,523-529$.

Spina, D., Page, C.P., 2002a. Asthma - a need for a rethink? Trends Pharmacol. Sci. 23, 311-315.

Spina, D., Page, C.P., 2002b. Pharmacology of airway irritability. Curr. Opin. Pharmacol. 2, 264-272.

Sullivan, S.D., Meltzer, E.O., 2003. Emerging therapeutic strategies for asthma management. J. Manag. Care Pharm. 9, 14-21.

Townley, R.G., 1992. Antiallergic properties of the second-generation H1 antihistamines during the early and late reactions to antigen. J. Allergy Clin. Immunol. 90, 720-725.

Wanner, A., Abraham, W.M., Douglas, J.S., Drazen, J.M., Richerson, H.B., Ram, J.S., 1990. NHLBI Workshop Summary. Models of airway hyperresponsiveness. Am. Rev. Respir. Dis. 141, 253-257. 